\title{
Pemanfaatan Media Pembelajaran Berbasis Teknlologi Sesuai Dengan karakteristik Gaya Belajar
}

Mayangsari Nikmatur Rahmi, M. Agus Samsudi,

*Corresponding Author.E-mail: mygsari96@gmail.com

Receive: $10 / 09 / 2020$

Accepted: 10/10/2020

Published: $30 / 10 / 2020$

\begin{abstract}
Abstrak
Latar belakang, tingkat pengetahuan,serta gaya belajar yang tidak sama serta mempunyai caranya sendiri dalam belajar. Penyesuaian pewujudansistem pembelajaran dengan gaya belajar peserta didik untuk memperoleh materi, model penyajian dan penyocokannya harus di sesuaikan. media sebagai segala bentuk dan saluran yang digunakan untuk menyampaikan pesan atau informasi. media pembelajaran merupakan sebuah bentuk fisik atau sebuah teknis dalam dunia pembelajaran yang dapat membantu pendidik mempermudah untuk menyampaikan materi pembelajaran kepada peserta didik sehingga memudahkan pencapaian tujuan pembelajaran yang telah direncanakan atau di rumuskan dengan baik. Pada zaman milenialsaatini, teknologi selalu menemani kehidupan manusia, tidak bisa terlepas dalam keseharian. Teknologi merupakan fitur baru di dunia pendidikan. Seperti sistem pengajaran berbasis multimedia.Undang-Undang Nomor 20 tahun 2003 berfungsi mengembangkan kemampuan dan membentuk watak serta peradaban bangsa yang bermartabat dalam rangka mencerdasakan kehidupan bangsa. Dengan demekian, pembelajaran di sekolah perlu dikembangkan untuk membentuk karakteristik belajar peserta didik. Pembelajaran disekolah memang tidak terlepas dari media pembelajaran dan sumber belajar dapat dikombinasikan berbasis teknologi, berapa diantaranya yaitu media audio, media visual, media audivisual, dan media serba neka. Dalam hal ini karakteristik gaya belajar merupakan hal penting yang dimiliki setiap peserta didik yang berbeda-beda sehingga dalam belajar membutuhkan cara yang ditempuh agar peserta didik memahami pelajaran. Setiap peserta didik memiliki gaya unik tersendiri dalam memahami pe;ajaran, adapun pilihan peserta didik terhadap gaya belajar merupakan cara terbaik dengan tujuan penyerapan pelajaran dengan cepat. Setiap peserta didik mempunyai kombinasi untuk memahami bagaimana caranya menyerap informasi, kemudian mengatur sendiri untuk memahami bagaimana caranya menyerap informasi, kemudian mengatur sendiri informasi yang didapat tersebut sehingga pemilihan pembelajaran tepat sesuai gaya belajar masing-masing peserta didik.
\end{abstract}

Kata Kunci: Media pembelajaran; Teknologi; GayaBelajar 


\section{PENDAHULUAN}

Pendidikan ialah suatu kewajiban yang harus dimiliki oleh setiap orang. Menurut $\mathrm{H}$. Fuad Ihsan (2005:1) mendeskripsikan yang sederhana bahwa suatu usaha manusia untuk mengambangkan dan menumbuhkan potensi bawaan yang ada di dirinya baik jasamani maupun rohani sesuai dengan nilai-nilai yang ada di dalam kebudayaan dan masyarakat. Oleh karena itu, dengan adanya pendidikan diharapkan dapat mengarahkan peserta didik untuk mampu mencapai sebuah proses kemandirian serta pendewasaan.

Kemajuan ilmu pengetahuan dan teknologi yang sudah memadai di era globalisasi sangat besar pengaruhnya dalam berbagai macam bidang. Pendidikan sebagai solusi bagian terpenting dari proses pendewasaan manusia tentu di satu sisi mempunyai andil yang sangat besar bagi pengembangan ilmu pengetahuan dan teknologi, namun juga di sisi lain pendidikan harus bisa memanfaatkan akan kemajuan teknologi serta ilmu pengetahuan agar bisa mencapai tujuan pendidikan secara efesien dan efektif.

Sebagaimana kita ketahui bahwa setiap manusia memiliki berbagai macam karakteristik yang berbeda-beda dan memiliki keunikan otak diantaranya belahan kiri dan kanan. Otak kiri tergolong dalam Sort term, sedangkan otak belahan kanan memiliki karakteristik Long term memory.

Salah satu karakteristik belajar yang berhubungan dengan mengolah, menyerap, dan menyampaikan informasi ialah gaya belajar. Gaya belajar merupakan suatu yang sangat penting yang harus dimiliki setiap orang. Sebagian peserta didik bisa belajar dengan sangat baik hanya dengan melihat orang lain melakukannya.

Maka dari itu, pemanfaatan teknologi yang sangat populer diera globalisasi ini sangat penting terhadap kebutuhan belajar dan dapat mempermudah akan kegiatan pembelajaran sehingga bisa membentuk kondisi yang efektif dan efesien dan untuk meningkatkan kualitas pembelajaran sehingga tidak terlalu mononton apalagi berkaitan dengan dunia pendidikan Islam, khususnya mediamedia yang berbasis teknologi saat ini.dunia Pendidikan melahirkan fitur baru.

\section{PEMBAHASAN}

Pengertian Media Pembelajaran

Pelaksanaan pembelajaran merupakan hasil integrasi dari beberapa komponen yang jelas memiliki tujuan pembelajaran dengan baik dan lancar dan memenuhi ketercapaian yang terpenuhi sesuai dengan fungsinya sendirisendiri. Ciri yang paleng utama dari kegiatan pembelajaran ialah adanya sebuah interaksi. Yakni, terjadi antara peserta didik dengan berbagai macam lingkungan belajarnya, baik itu dengan teman maupun pendidik bahkan dengan alat-alat dan media pembelajaran atau dari sumber-sember yang lain yang ada pada sekitarnya. Sedangkan ciri lain dari pembelajaran berkaitan dengan komponen pembelajaran itu sendiri seperti materi/bahan, tujuan, media, strategi, dan evaluasi pembelajaran.

Media pembelajaran menurut Menurut AECT (Association of Education and Comunication Technology, 1977) memberikakan batasan mengenai media yang bertujuan sebagai saluran menyampaikan informasi dan pesan.. Sedangkan menurut Gagne dan Briggs (1975) media meliputi slide, foto, vidio kamera, gambar, buku, tape recorder, kaset, video recorder, televisi, film, gambar, grafik, dan computer. Jadi dapat disimpulkan bahwa media sebagai sumber belajar atau fasilitas yang beruoakan bentuk fisik yang mengandung materi-materi intruksional dilingkunga pendidikan yang mendukung suatu proses belajar mengajar untuk merangsang peserta didik.

Menurut Gegne (1992) mengatakan sebuah jenis perangsang yang bisa membuat tumbuh sebagai jenis komponen terhadap siswa agar bisa belajar. Sedangkan Heinich dan 
Molenda mengartikan bahwa media sebuah saluran untuk berkomunikasi termasuk film, diagram, televisi, komputer, materi tercetak, dan instruktur.

Dalam buku Oemar Hamalik yang di kutip Muhson berpendapat bahwa media ialah suatu ekstensi yang ada kemungkinan untuk mempengaruhi orang lain dan yang tidak berhubungan kontak langsung dengan dia itu sendiri. Sesuai pendapat ini bahwa media komunikasi meliputi televisi, surat-surat, telepon, dan film, dan bahkan jalan raya daa jalan kereta apo merupakan media yang memungkinkan seseorang berkomunikasi dengan orang lain.

Pengertian media pembelajaran antara lain disampaikan oleh Oemar Hamalik bahwa media pembelajaran dibagi menjadi dua yaitu dalam arti luas dan sempit. Dalam arti luas, media tidak harus meliputi komunikasi yang lagi tren saat ini, tetapi juga mencakup alat-alat sederhana, seperti fotografi, slide, diagram, dan bagan buatan pendidik, barang obyek nyata, serta kunjungan di luar sekolah, sedangkan dalam arti sempit media pembelajaran hanya meliputi media yang dapat digunakan secara efesien dan efektif dalam proses pembelajaran yang sesuai tujuan.

Dalam pengertian pendapat lain pakar pendidikan menurut Brings yang ditulis oleh Steff Adam bahwa segala sesuatu yang berupa bentuk nyata atau benda fisik yang dapat menyajikan pesan yang dapat merangsang peserta didik untuk belajar misalnya kaset, buku, film dan lainlainnya. Sedangkan Wiblbur Scharamn berpendapat teknik yang membawakan informasi atau pesan-pesan pembelajaran. Pendapat lain yang dikatakan Yusuf Hadi Miarso bahwa Media Pembelajaran ialah merupakan suatu yang bisa mendapatkan rangsangan yang terjadi dalam proses belajar dan mengajar.

Dengan berbagai definisi diatas dapat disimpulkan bahwa media pembelajaran merupakan sebuah bentuk fisik atau sebuah teknis dalam dunia pembelajaran yang dapat membantu pendidik mempermudah untuk menyampaikan materi pembelajaran kepada peserta didik sehingga memudahkan pencapaian tujuan pembelajaran yang telah direncanakan atau di rumuskan dengan baik. Dan bisa diartikan lain media merupakan fasilitas wadah yang bisa disalurkan kepada penerima, dalam dunia pendidikan anatara pendidik dan peserta didik akan menyampaikan materi pembelajaran dengan tujuan yang ingin tercapai sesuai yang telah direncanakan.

\section{Teknologi Informasi dalam Pendidikan}

Di era revolusi 4.0 saat ini dalam dunia pendidikan sangatlah penting terkait dengan berkembangnya zaman. Hal ini semakin mudah pendidikan seharusnya memiliki saluran atau sarana prasarana yang dapat dipakai untuk menyiarkan progam pendidikan. Teknologi dapat juga melahirkan fitur baru dalam dunia pendidikan. Sistem pengajaran yang berbasis multimedia misalnya contohnya seperti gambar, vidio, teks, dan suara. Sehingga dalam menyampaikan materi tidak terlalu monoton justru mengundang ketertarikan peserta didik serta memudahkan penyampain terkait materi. Peserta didik dapat mempelajari materi secara mandiri dengan penggunaan komputer yang dilengkapi progam berbasis multemedia. Sesuai dengan masa kini banyak perangkat lunak yang tergolong sebagai edutaiment maksudnya perpaduan antara education (pendidikan) dan entertaiment (hiburan).

Berdasarkan Undang-Undang Nomor 20 tahun 2003 tentang sistem pendidikan nasional menyebutkan bahwa pendidikan nasional berfungsi kemampuan dan 
membentuk kepribadian sifat dar kesesuaian bangsa bertujuan untuk mencerdaskan kehidupan bangsa. Pokok dari sebuah pondasi pembelajaran yang kreativ dan inofativ sehingga akan tercapainya proses belajar menyenangkan dan lebih berguna, bermanfaat bagi genarasi-genarasi para pemuda.

Media pembelajaran berbasis teknologi menurut sahlan prasetyo yang ditulis oleh putu bahwa bahwa bisa memberikan kontribusi sekaligus fasilitas dalam memahamkan materi ajar yang ingin di sampaikan oleh para pendidik sehingga peserta didik dengan mudah untuk memahamo terkait materi yang diajarkan tersebut, serta menambah wawasan pengertahuan teknologi informasi bagi peserta didik.

Macam-macam bentuk media di lingkup pembelajaran, pengelompokkan atau media dan sumber belajar dapat juga di lihat dari bentuk jenisnya, yaitu media yang berkhusus audio, media untuk visual, media audiovisual, dan media serba neka. Adapun pengelompokkan pembagian masing-masing dibawah ini :

1. Media audio yaitu : radio, televisi, telefon, mp3, tape recorder, pita audio dan lain sebagainya.

2. Media visual diantaranya buku, ensiklopedia, gambar, foto, film rangkai, majalah, buku-buku referensi, surat kabar, ilustrasi, kliping, proyektor, diagram dan sketsa, poster, peta, globe dan lain-lainnya.

3. Media audiovisual

a. Audiovisual gerak : vidio, CD, film rangkaian, televisi, suara, gambar yang ada suaranya.

b. Audiovisual diam : slide dalam suara, film rangkai suara
Adapun kriteria pemelihan media bersumber dari konsep bahwa media sebagai sistem intrusisioanal secara keseleruhan. Dan ada beberapa faktor yang harus bisa dipertimbangkan ketika memilihi sebuah media, adapun faktor tersebut diantaranya:

1. Ada biaya untuk membeli atau diproduksi sendiri, dan adanya fasilitas serta tenaganya.

2. Adanya keterbatasan sumber setempat, maksudnya apabila media yang bersangkutan tidak ada di sumber setempat, akan diharuskannya membeli atau memproduksi sendiri

3. Terkait dengan faktor keluwesan, maksudnya disini bertahan tidaknya sebuah media untuk berjangka waktu yang panjang, artinya dipergunakan dimanapun dengan peralatan yang lain dan kapanpun yang mau menggunakan bisa dibawah dengan tangan sendiri dan bisa di buat dipindah-pindah.

4. Efektifitas dalam jangka waktu yang lama lebih di prioritaskan.

\section{Karakteristik Gaya Belajar}

Karakteristik gaya belajar menurut Sleels dan Richey ialah bagian-bagian penting yang pasti dimiliki oleh semua orang, didalam dunia pendidikan bisa diartikan seperti pengalaman peserta didik yang berpengaruh pada kegiatan keaktifan proses belajar mengajar. Karakteristik ini bertujuan untuk menceritakan bagian-bagian kepribadian seorang peserta didik yang harus diperhatikan untuk kepentingan pembalajaran. 
Jurnal Edumaspul, 4 (1), Year 2020 - 359

Mayangsari Nikmatur Rahmi, M. Agus Samsudi ,

Tingkat kemampuan setiap orang dalam memahami pelajaran jelas berbeda-beda. Ada yang dengan langsung cepat menangkap dan ada yang terlambat untuk memahami. Oleh sebab itu, ada berbagai macam yang bisa menempuh agar dapat memahami pelajaran dan informasi yang sama dalam bentuk proses belajar dan mengajar. Gaya belajar merupakan yang unik yang dimiliki oleh setiap masing-masing peserta didik, apapun yang dia pilih perbedaan gaya belajar itu menunjukkan langkah cepat dan terbaik bagi setiap orang masing-masing dengan tujuan menyerap sebuah informasi dari luar dirinya. Jika seorang pengajar mengetahui serta memahami akan masing-masing gaya belajar setiap anak maka akan lebih mudah memberikan dan mentaransferkan ilmu pengetahuan yang baik dan tepat dan menghasilkan maksimal bagi dirinya.

Gaya belajar merupakan suatu pendekatan untuk mengetahui penjelasan terkait bagaimana individu belajar setiap orang atau juga bisa diartikan suatu cara yang di tempuh oleh seseorang untuk berkonsentrasi pada suatu proses, dan memahami informasi yang baru dan sulit difahami dari berbagai presepsi yang berbedabeda. Setiap gaya pasti berbeda disetiap individu setiap orang dan pasti mempunyai perbedaan tersendiri anatara orang yang satu dengan yang lain. Dengan demikian, secara umum gaya belajar bisa diartikan mengacu pada bentuk kepribadian, perilaku, kepercayaan, dan pilihan yang dilakukan individu untuk membantu dalam proses belajar mereka dalam situasi yang sudah dikondisikan saat itu.

Berbagai pendapat gaya belajar menurut Gunawan (2003 : 139) ialah sesuatu cara yang lebih dominan disukai oleh setiap oarang dalam melakukan memahami, berfikir, dan berproses, dan mengetahui sebuah informasi. Contohnya, ketikan ingin belajar tentang binatang, bisa dengan membaca buku, atau bisa langsung ketempat kebun binatang. Sedangkan menurut DePoter dan Hernacki (1999), gaya belajar diartikan setiap orang mempunyai kombinasi sendiri dan cara memahami bagaimana menyerap akan adanya informasi, lalu kemudian menagtur sendiri informasi yang didapat tersebut.

Berdasarkan dari kedua pengertian pendapat tersebut dapat disimpulkan gaya belajar merupakan suatu cara kepribadian yang konsisten cenderung disukai oleh setiap orang dalam melakukan kegiatan menyerap informasi, memahami, berfikir, mengolah dan memproses sebuah informasi dan mengingatnya dalam memori. Dengan demikian, efektif tidaknya berjalannya belajar mengajar akan sangat kelihatan antara media pembelajaran dan metode yang digunakan oleh pendidik dengan kecenderungan gaya belajar peserta didiknya.

Menurut Nasuition (2008) gaya belajar ialah cara beraksi peserta didik dengan menggunakan perangsang yang 
diberikan oleh pendidik yang diterimanya dalam proses belajar. Para peneliti menemukan adanya berbagai sumber gaya belajar pada peserta didik yang bisa digolongkan menurut kategori tertentu. Tiga gaya gaya belajar menurut Henarcky dan Deporter diantaranya sebagai berikut:

1. Visual, yakni menjelaskan individu lebih menyukai memproses pengetahuan dengan cara penglihatan, tipe gaya ini cenderung perlu melihat sesuatu dulu karena mereka memiliki kenyamanan dalam belajar contohnya penggunaan garis, warna-warna, dan bentuk. Pada pendapat lain dalam buku Bobi (2008: 68) yang ditulis oleh harapan bahwa tipe visual ini harus di dorong membuat banyak simbol dan gambar dalam catatan mereka. Karena, peserta didik visual belajar terbaik saat mereka mulai dengan gambaran keseluruhan. Adapun ciri khas karakteristik anak yang bertipe visual ini diantaranya : mempunyai kepekaan sendiri yang sangat kuat pada warna, kebutuhan melihat informasi harus secara visual dalam memahaminya, cenderung diam tak banyak bicara, sering salah menyampaikan kata pada ucapan, merasa kesulitan berbicara secara langsung dengan orang lain, sulit menerima kritikan secara lisan.

2. Auditori, yakni mengandalkan pendengaran untuk mendaptakan pengetahuan baru atau informasi yang di dapat, orang yang bertipe ini hanya butuh penyampaian yang jelas dan baik sehingga diterima dengan yang jelas dan baik pula. Contohnya dalam hal ini didunia pendidikan cenderung lebih memperhatikan dan mendengarkan apa yang disampaikan oleh pendidik tersebut dengan seksama. Adapun pngertian lain dari model pendengaran ini mungkin lebih suka merekan dan menlis apa yang telah didengar. Adapun ciri karakteristik dari tipe ini ialah biasa menyerap informasi melalui pendengaran, menulis dan membaca cenderung kesulitan, dan sulit akan meerima informasi yang berupa tulisan secara langsung.

3. Kinestetik, gaya belajar model tipe ini lebih menyukai melalui gerakan, sentuhan, dan praktek. Bisanya orang yang bertipe ini merasa lebih mudah untuk mempelajari sesuatu tidak hanya sekedar membaca buku tetapi juga mempraktikkannya. Peserta didik yang bertipe gaya ini menyukai proyek-proyek terapan, suka belajar gerakan dan paleng baik menghafal informasi dengan mempraktekkan dengan gerakan disetiap fakta kenyataanya. Adapun ciri dari anak yang berkarkteristik dengan gaya ini sebagai berikut : lebih menempatkan tangan sebagai alat informasi pertama dengan tujuan selalu diingatnya, suka jika materi pembelajaran disertai dengan gerakan fisik, mengandalkan memegang dengan tangan sebagai menyerap informasi dan tidak harus membaca penjesannya secara beruntun, memiliki kemampuan berkomunikasi dengan bentuk tim dan kemampuan mengendalikan garak tubuh, dan dalam situasi pembelajaran cenderung tidak bisa tahan duduk terlalu lama untuk mendengarkan materi pelajaran.

Oleh karena itu setiap peserta didik memiliki gaya tersendiri sehingga pendidik dapat menemukan dan menyesuaikan gaya mengajar. 
Manfaat media pembelajaran berbasis teknologi kesesuaiannya dengan gaya belajar

Secara umum media pembelajaran sudah sangat canggih dari berkembangnya zaman ini, manfaat media dalam proses pembelajaran ialah memperlancar komunikasi antara pendidik dan peserta didik sehingga situasi pembelajaran bisa efektif dan efesien. Tetapi secara lebih khusus manfaat media ada yang lebih terinci, Kemp dan Dayton merumuskan beberapa manfaat media dalam pembelajaran diantaranya:

a. Proses pembelajaran menjadi lebih interaktif. Hal ini karena media pembelajaran berbasis teknologi dapat memadukan berbagai gaya belajar yang dimiliki oleh peserta didik sehingga mampu menumbuhkan motivasi pada diri peserta didik. Munculnya motivasi ini dapat menciptkana kelas lebih intraktif.

b. Efesien dalam waktu dan tenaga. Sebagaimana yang dijelaskan di atas, teknologi menjadikan proses pembelajaran lebih efisien, karena media pembelajaran dapat mempercepat pemahaman di antara peserta didik dengan berbagai gaya belajar. Selain itu, pendidik juga terbantu baik dari segi waktu maupun biaya pada saat membuat media pembelajaran.

c. Penyampaian materi pelajaran dapat disamakan. Ini menunjukkan bahwa dengan adanya media pembalajaran berbasis teknologi mampu menyamakan persepsi di antara peserta didik. d. Proses belajar mengajar jauh lebih menarik dari pada yang tidak ada medianya. Karena tanpa media pembelajaran, peserta didik dengan berbagai gaya belajar karena akan merasa bosan. Misalkan saja peserta didik dengan gaya belajar visual. Mereka akan kesulitan menerima pengetahuan karena proses pembelajaran tidak sesuai dengan gaya belajar mereka. Mereka akan lebih tertarik dengan gambar-gambar yang mampu menstimulus perhatian mereka.

e. Dapat menumbuhkan sifat optimis dan positif pada peserta didik terhadap materi yang disampaikan dan proses selama pembelajaran.

f. Merubah peran pendidik kearah yang lebih produktif daan lebih positif.

g. Menigkatkan kualitas belajar hasil belajar peserta didik.

h. Bisa memungkinkan proses belajar dilakukan dimana saja dan kapan saja.

Adapun kesesuaian dengan gaya belajar terhadap media pembelajaran sangat saling menguntungkan, sudah jelas dari beberapa macam-macam manfaat yang sudah terterah diatas. Gaya belajar sangat mempengaruhi pemahamannya terkait materi pelajaran yang disampaikan. Ketika peserta didik tipe belajarnya bersifat auditori, pendidik tinggal mengajar menyuruh menulis yang diajarkan dan menyuruh memahami sendiri apa yang sudah ditulisnya. Selanjutnya, jika pendidik memberikan sebuah tes dan kemungkinan besar mendaptakan nilai tes yang dikerjakan anak tersebut akan rendah. Tidak menutup kemungkinan dengan anak yang bersifat gaya belajar visual pendidik memberikan ceramah saja dan peserta didik cenderung hanya mendengarkan 
apa yang disampaikan. Begitupun dengan gaya belajar yang bersifat kinestetik mereka hanya butuh pemahaman dengan gerakan.

Disinilah perlu media yang bisa menyesuaikan masing-masing dengan gaya belajar, bagaimana pendidik bisa menyesuaikan masing-masing gaya belajar yang berbeda-beda. Dengan berkembangnya saat ini banyak media yang sudah mumpuni untuk kegiatan belajar mengajar yang sangat canggih.

Adapun masing-masing contoh gaya belajar yang sesuai dengan media saat ini gaya belajar yang bersifat visual menyertakakan gambar, grafik, bentukbentuk. Gaya belajar auditori contohnya radio, mp3, yuotube, dan lain sebagainya. Sedangkan gaya belajar yang bersifat kinestetik cenderung lebih harus mencotohkan dengan gerakan, contonya gerakan-gerakan yang menginisalkan sebuah benda, contohnya pendidik mempraktekkan gerakan tangan keatas mengibaratkan contoh gunung.

\section{Kesimpulan}

Pembelajaranyang sedang kita lakukan pada saatiniyaitu di zaman revolusi $\quad 4.0 \quad$ yang semuanyamembutuhkanteknologi yang terus berkembang dengan cepat dan dapat diakses di manapun, memerlukan penanaman sejak dini untuk mengetahui teknologi yang sedang kita pakai. Pemanfaantan yang tidak tepat sasaran bisa berpengaruh terhadap perserta didik yang menerima sumbersumber baru dari teknologi yang kita berikan kepada peserta didik.

Setiappesertadidikmemilikicarauni kdalammemahamipelajarannya, tekknologiberperandalamkesuksesanpese

rtadidik. Cara uniktersebut di milikisetiappesertadidik yang berbedabedasesuaitingkatkemampuan dan kecondonganpesertadidikuntukmemaha mipelajarannya

Maka jika peserta didik tidak diberikan teknologi yang tepat sesuai dengan gaya belajar mereka, maka pembelajran berbasis teknologi tidak dapat digunakan dengan baik, karena setiap peserta didik memiliki cara belajar tersendiri yakni kemampuan mereka menangkap informasi yang kita berikan, baik yang berupa pemanfaatan teknologi berbasis, visual, auditori, animasi, Vidio dan simulasi.

Pemanfaatan yang sesuai dapat menyesuaikan dengan gaya belajar yang penulis sebutkan diatas akan berpengaruh terhadap daya tangkap dan pemahaman peserta didik untuk memhami pembelajaran yang sedang berlangusung.

\section{DAFTAR PUSTAKA}

Azhar Arsyad, Media Pembelajaran, Jakarta: PT. Raja Grafindo Persada, 2003

Ali Muhson, "Pengembangan Media Pembelajaran Berbasis Teknologi Informasi" . Jurnal Pendidikan Akutansi Indonesia, Vol VIII No 2, Jurnal Pendidikan Akutansi Indonesia 2014

Steffi Adam dan Muhammad Taufik, Pemanfaatan Media Pembelajaran Berbasis Teknologi Informasi Bagi peserta didik Kelas X SMA Ananda Batam", Volu 3 No 2 CBIS Journal 2015

Ni Putu Eka Merliana, Pemanfaatan Teknologi Informasi Berbasis Android Sebagai Media dalam Pembelajaran Hindu, vol 1 edisi I, Jurnal Setya Widya 2018 
Ali Muhtadi, Karakterristik Gaya Belajar Ditinjau Dari Preferensi Sensori Dan Lingkungan, Jurnal Teknodika 2006

Syarfuni dan Verawati, Analisis Karakteristik Gaya Belajar Mahapeserta didik PBI STKIP Bina Bangsa Banda Aceh, vol VIII No 1, 2017

Harpan Reski Mulia, Pembelajaran Berbaris Multimedia : Dalam Memahami Keberagaman Gaya Belajar Anak, vol 5 no 2, 2019

Ariesta Kartika Sari, Analisis Karakteristik Gaya Belajar VAK (Visual. Auditorial, Kinestetik), Mahasiswa Pendidikan Informatika Angkatan 2014, vol 1 no 1, 2014

Nunuk Suyani,Pengembangan Media Pembelajaran Berbasis IT, Vol 3 no 2, Jurnal.fkip.uns.ac.id 2016,

Yeni Mutiaraningsih, A. Jusriana, Hubungan Gaya Belajar Peserta Didik Terhadap Kemampuan Memahami Konsep Fisika Kelas Vii Smpn 5 Soromandikabupaten Bima, volume 4 no 2, journal.uin.alaudin 2016

Muhammad Ali, Pengembangan Pembelajaran Interaktif Mata kuliah Medan Elektromagnetik, vol 5 no 1, jurnal Edukasi, 2009 